
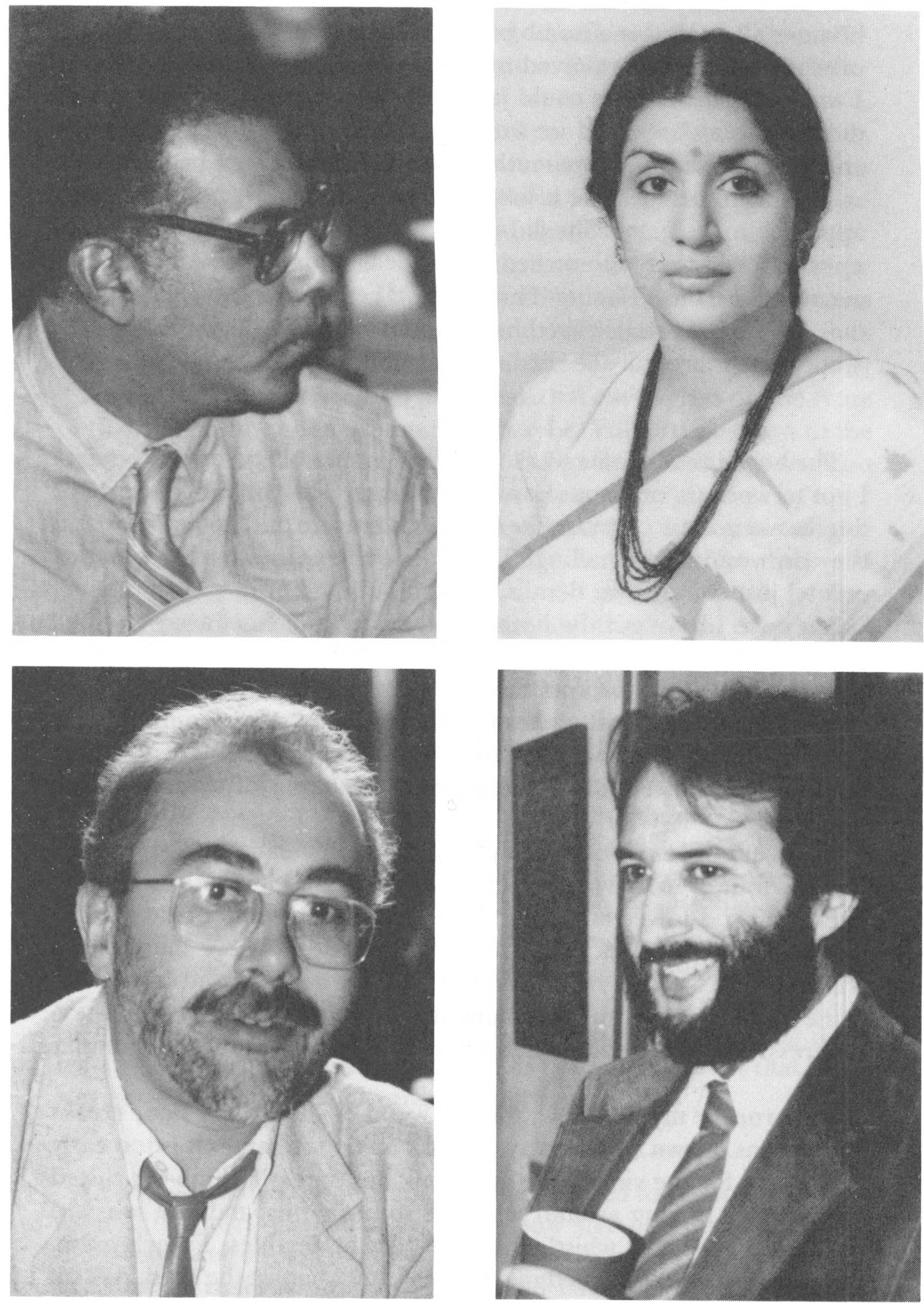

(Clockwise) Wayne Brown, Lakshmi Kannon, Herman Lara Zavala, Marc, Bloch, photographs courtesy of the International Writing Program. 


\section{INTERVIEW WITH MEMBERS OF THE INTERNATIONAL WRITING PROGRAM}

Sheila McIntosh

SINCE 1967, THE International Writing Program has brought some 700 writers from over 75 countries to the University of Iowa. During their three-month stay in Iowa City, the writers live together on the eighth floor of the Mayflower Residence Hall. They are free to do what they choose: to write, to participate in readings and lectures, to socialize. The following interview was conducted last November with four 1987 members of the IWP.

MARC BLOCH (France) taught French at Lawrence University from 1968 to 1970, and was a journalist for Agence France Press in Southeast Asia in the seventies. His novel L'Emotion, L'Emeute draws on his experiences abroad and on the emotional impact that the events of the year 1968 and the Vietnam War made on the lives of a generation.

WAYNE BROWN (Trinidad) is a columnist for the Trinidad newspapers Daily and Sunday Express, and a lecturer at the University of the West Indies in Jamaica. His collection of poems On the Coast won the Commonwealth Prize for Poetry. He is the biographer of Edna Manley and co-edited editions of the poetry of Cecil Herbert and of Derek Walcott.

LAKSHMI KANNAN (India) writes under the pen name "Kaaveri." She has written six books in English, including the poetry collections The Glow and the Grey and Impressions. She is also the author of a collection of short stories in Tamil, and has translated her own work from Tamil into English.

HeRnAN LARA Zavala (Mexico) is coordinator of the Narrative Workshop at the National Institute of Fine Arts in Cuernavaca, and professor of English and American literature at the National Autonomous University of Mexico. He has published two collections of short 
stories and numerous essays, and is now at work on a novel.

In conversations with other writers who have participated in the International Writing Program, I've gotten the impression that there are three distinct sides to the experience: first, being in the United States for an extended period of time, and in a certain type of place; second, living with a group of 30 writers from 26 countries; and third, having time and means to devote to writing, which may be something you haven't had in the past. How have these experiences affected you? Has any one of them been more important than the others?

WB: I'd never spent any time in the United States before, but I'd read about it and seen its television programs, and it was pretty much what I expected. But of course it's different living it than speculating about it. Being here in Iowa City has been a little artificial, like looking at something behind glass, but in the balance I've been glad to be here.

MB: This isn't my first time in the States, actually it's not even my first time in Iowa. I was in Iowa in 1964 for a month, and part of my novel takes place here. When I was invited [to the IWP] I thought it was extremely amusing to have Iowa catching up with me 23 years later, in a kind of Nabakovian circle.

Were you with the IWP in 1964 ?

MB: No, I was invited by friends in Sioux City. I had my picture in the Sioux City Gazette.

HL: I think the three points you mentioned have a different significance for each of us. I had already come to know the States fairly well-I grew up fairly familiar with American culture, I had been in California, in New York, in Chicago. But of course, living in Iowa for three months as a forty-year-old man has changed my views somewhat. Being in Iowa has been interesting because of the period this country is living now. I see some drawbacks now; the American culture I knew before was more liberal and open-minded. I think you're going through a conservative stage; I see attitudes now that are very different from what I saw at the beginning of the sixties. Of course, there's a difference between being in a city like Chicago and being in Iowa. It's been extremely interesting and invigorating to have the time to write. Unfortunately, I could only devote about half of my time to writing, because we had so many things to do, especially during the celebration of the program's anniversary. Living with other 
writers was an important part of being here; it was interesting to see what kind of literary trends are developing around the world, to see my position to them and live with people from such different countries.

WB: What I like most about America is something I had not realized: I think Americans really like the idea of America, and they do not equate themselves with America. Not quite. The British equate themselves with Britain, they are Britain. America is a young country, and there is not yet the perfect marriage between Americans and America. America is an idea, an ideal, to the people here, and they really like it, almost as if it were a woman they were in love with. I like that very much; I've never seen it before, that precise distance between a people and the idea of their country, and I think it brings out the best in them. Obviously, they're susceptible to abuse by advertising agencies, by politicians, and so on. But in the day-to-day life of the country, this liking of the idea of America I find very nice. The thing I like least about America, something I hadn't realized, is how utterly monetary the society is. I come from a materialist society myself, a lot of countries in the West are materialist, but in America it's as if all the niches have been filled, all the illusions have been swept away. If it makes money, it's good.

LK: My first stay in the United States was spent as a student on a shoestring budget, and it's been quite a different experience this time, living in the Mayflower among the students. I was interested by the number of options open to young people in the States. They're more able to realize their options in life, and seeing that made me wonder how they were going to make their choices and how they would understand those choices.

WB: This hasn't really been a time for me to write; it's been a time for reflection. It's been very useful for me to live with a number of writers from very different parts of the world, because it has given me a backdrop of contrast; I know a little more about myself and about my writing than I did before I came here. I know myself in contrast to them and their writing.

MB: I would agree that being with people from so many different countries was the best part of the program. If the readers of this interview could listen to the tape, and hear the four different accents-Caribbean, Mexican, French, Indian-and different ways of speaking English, that would tell them about the richness of the 
experience in a way. I regret that there were some language barriers, with some of the Chinese writers who didn't speak English, for example. But the experience was very good.

LK: I came here with a very rigid work timetable I wanted to stick to, because this time was a luxury for me. I've got a job at home, as most of us do; we don't wake up as.writers, with a license to get up late and continue writing. So I thought I would take advantage of this luxury and stick to my timetable, but somewhere along the way I found myself throwing it out the window. I just abandoned it, and then I went through a phase of guilt about not doing enough work, and worrying about why I wasn't doing enough work. In the end I realized that for the past three or four years I've been hanging onto my identity as a Tamil writer, and not just an English writer, and that has holed me into a very narrow microcontext in India, where Hindi dominates the scene and Tamil is a minority language. While that gave me a very sharp sense of communicating with people who are the semiliterate ones and the rewarding experience of being with people other than those of my class, it was also something I needed to break away from for a time. This was an opportunity to do that, and so I felt it was all right if I didn't write those six fantastic pages every day. It's been important for me to talk to my colleagues here, especially those who found a miraculous way of communicating without English.

My next question concerns the reputation of the Writers' Workshops at the University of Iowa. Whenever I've tried to explain the concept of writers' workshops to friends in Europe, they're surprised that such a thing even exists, and they seem doubtful as to its value. The feeling seems to be that either you have it or you don't-if you have it nothing can stop you from being a writer, and if you don't no amount of time in the classroom can help you become one. Do you feel that workshops are valuable?

HL: I do believe in workshops, although I don't believe they can make a writer out of someone who isn't already one. I think that workshops can be very useful, to help people with talent make the most of their time and to help them grasp the elemental parts of writing without having to do it all on their own. I don't favor very rigid workshops in the sense of their being writing classes, but young writers should be helped to find their own voice. That would be the point of it for me. There are writers' workshops in Mexico now; they were started by a well-known writer named Juan Jos Aureola. There's a lot of support for them right now. 
WB: I'm afraid I agree with your European respondents on this question. After looking at work by students in Iowa Writers' Workshop, which is supposed to be pretty famous, I was very disappointed. What I found was a kind of hothouse atmosphere, with people who didn't have to be writers and shouldn't have been writers, because everybody doesn't have to be a writer. But they've chosen this as a career, and so you have writers writing for writers and there is a kind of . . . I would use the word decadence. I've worked pretty steadily now for about eight weeks with one or two people, one of whom was very gifted ... . she was a freshman who had just come to the University of Iowa, and I felt, the more I read of her work, that her strength was in her independence of thought. But there's not enough of that here. So I'm afraid that's my opinion of the Writer's Workshop, which is a paradox and a pity, because I've read the work of the people who teach here and they're very good writers. In terms of the results, I think that something's wrong with the system.

MB: I would have to agree with that.

Over the years the IWP has hosted many writers from countries where more than one language is spoken-and the dominant language of national literatures is often a colonial language. What is represented by the decision to write in English as opposed to Tamil, for example, or to write in both of them? How do those of you who write in English relate to British and American authors, who write in the same language you do but represent different cultures?

WB: I believe that with the possible exception of Lakshmi, I am the only native speaker of English in this group. How do I make this language mine? It is my language, the only one I ever had. I see American literature as a flowering, an offshoot of British literature; I think that at the present time it has surpassed British literature. But nonetheless, it derives from that root. I see West Indian literature, which as you know has produced some of the best writers in the world today, Derek Walcott, V.S. Naipaul, and so on, as just like American English, an offshoot of British literature, which hopefully has surpassed its model in many ways.... The colonial issue, I think, is thought of in too static a fashion. For example, there's a game, cricket, it's a British game. But when a team, and I'm sorry to sound nationalistic here, like the West Indies cricket team becomes a world champion and beats the British for ten years straight, then it's no longer a British game. And a student of cricket would see the imprint of West Indian sensibility upon the game. I think you can see the 
imprint of West Indian sensibility upon what we broadly call English literature . . . as I'm sure you in America can see the imprint of Black American literature upon White American literature. So to me it's a quarrel without any tension, a rhetorical quarrel. This is my language; I use it somewhat differently than the British do, but that's all to the good and glory of the English language.

LK: Because translations have become very crucial and urgent in my country, psycholinguisticians give us a very clinical kind of data on how what is translated into English from other languages has a quality and a texture quite different from what could be originally written in English. In the same way, as Wayne said, the English written by a Trinidadian or an Indian settled in Trinidad like V.S. Naipaul has a quality to it that no Englishman could have written. This brings us to the importance of languages written in the vernacular. Personally, I find it tremendously exciting to keep up with the strain and stress of being an amphibian, writing my poems in English and my prose in Tamil. I like the struggle. I'll always work in both languages, but I hope I don't go divergent. I hope I find a center where the two meet.

I know that some of you have worked as journalists. My next question concerns the growing popularity in this country of "literary journalism," writing that combines the realism of journalism with the techniques of fiction. Is this type of writing being done in your countries?

WB: What you say is true, there is a new type of journalism which eschews the objective, which is subjective and places the reader in the center of it. I write as a freelance columnist, and I'm lucky in being free to write about anything I want, whether it's chess or politics or literature. But the fact that my writing is published in a newspaper is significant, and I'm sure it has changed my work as a writer, because of the immediacy of the relationship between the journalist and his audience. I write a piece today that goes into the newspaper tomorrow, and while I'm writing a piece for the next day I'm getting phone calls commending me or cursing me for the piece in today's paper. It has been a happy experience for me in that I've been writing for many years and I never expected to have such an immediate relationship with such a wide audience. The pitfall, of course, is that you do the easy, popular thing. I can only hope I have avoided that. But the climate of today, in which you can write for a newspaper and use the first person pronoun and employ the techniques of fiction-description, narration, characterization-is one that has formed me as a writer much more than I ever thought it would. 
HL: I think one of the great discoveries of twentieth century literature was Truman Capote. I have heard it said many times that the headlines of the New York Times are much more dramatic than anything one could dream up; and I think that Capote discovered that it was possible to lend the insight of the novel to something that happened in real life-in what he called nonfiction novels - and make the reader believe that what he's reading is true, and isn't just the fantasies of the author. I think these journalists who can write like novelists have given a real lift to literature; it requires a great talent to be able to see beyond mere appearances. And it's better to write about something which is real but shows a sort of inner world than a sloppy novel.

WB: I agree entirely - and I would add Norman Mailer as another example. I think he has had a profound influence on the kind of writing we're talking about.

MB: I've worked as a journalist, although I haven't been as lucky as Wayne in being able to choose my topics. I was covering the garbage that Americans were spilling in Southeast Asia in the seventies-for a news agency, the AFP - and I had to write many pages every day. But when I write fiction I write what I feel like writing, and I think I've tried to use my experiences as arjournalist in my novel, to use some journalistic techniques . . . I almost said tactics. In addition to Capote and Mailer, I would point out how John Dos Passos used news or events as backgrounds for fiction.

LK: I'd like to mention not only writers as journalists, but what journalists could do to writing. In India, and I would venture to say elsewhere, journalists have been falling into a trap of their own making, through their use of clichéd terms. An example is that in talking about political figures, anybody who's balanced, who has more conservative values, who has a message of peace, is called a political "moderate"-and you know there's an insinuation that the man is very weak or is sitting on the fence. This kind of clichéd phrase is showing up even in literature, for people who are considered feminists or not feminist enough, or somebody will be dismissed as too moderate because she has a message of harmony or peace. I discussed this with Alice Walker, whom I interviewed recently in San Francisco. She agreed that journalists who review books are getting very insensitive to literature; for example, she feels that if at this point she, as a Black American writer, takes a moderate stance, that's a very radical thing. 
But how many people will understand that? That's what bothered her.

WB: We had a change of government in Trinidad after the last elections, for the first time in thirty years. There was a journalist at the newspaper for which I write named Keith Smith, he is really a writer who has been unlucky and ended up as a journalist, but he covered the government's re-election campaign and he covered it as a writer. It is now generally agreed in my country that his writings about the campaign, since he wrote them not as a journalist but as a novelist, had a disproportionate influence in bringing down the government. He didn't simply say, "At this meeting, Minister So-and-So said such-andsuch . . ." He looked at their faces as they said it, he looked at the clothes they had on, he stripped them naked in an extraordinary kind of way. I would hold him $10 \%$ responsible for what came about . . . and if things had been handled by straight journalism, it would not have come about. It was quite extraordinary.

Every year there are more men than women among the IWP writers. Lakshmi, do you think your experience here has been different than that of your male colleagues?

LK: I often felt the male-female stereotyping that one finds so much in America, especially during the anniversary celebrations. During two or three of the formal dinners, there were several returning writers who had the following reactions to me: one man said, "Oh, of course you're from India, anyone could see that . . . where is your husband? Can I meet him?" So I told him, "I am the husband, I am the wife, I am the writer." Another gentleman said, "So, my dear, you've been given an American holiday by your husband. How are you enjoying it? Is this your first visit?" Once again, I had to tell him that I am my own wife. These are the situations I found, situations which, however much it surprises you, do not happen all that much in India. We do not have this kind of stereotyping. We have many saint-poets . . . poetesses? I don't like that word . . . so we have a very strong sacred tradition of poetry, and we've had very good women poets. It's not that way here.

One final question. As members of the IWP, you've all been cultural ambassadors of a sort. Have you encountered any misconceptions that surprised you? What is the one thing you'd most like Americans to know about your countries?

MB: I was very surprised to see that France does not exist in American 
newspapers. I've been reading the New York Times every day, and there have been very few articles, and never about mainstream issues. During the recent stock market crisis, for example, the papers listed the rate of the dollar against the yen and the mark, sometimes the pound, never the franc. That's all right . . . but it's interesting to see that France doesn't exist at that level. The only reference I found during that period was at the moment of rumors of French devaluation against the mark . . . they said that the beaujolais would be cheaper compared to other wine.

LK: I felt that I was reaping the unpleasant harvest of a very unfortunate error on the part of my country some centuries back, when they decided to call it India instead of Hindustan. The ignorance about India, what it is and its context in world issues, is appalling; I felt terribly alone whenever I met groups of grade school and college students, because India here is an adjective for the tribals, for the Mexican Indians, the Nicaraguan Indians, everybody except the Asian Indian, who is a Hindustani . . . so every time I was asked, "Are you an Indian?" I found myself explaining, "I'm an Asian Indian." I think you ought to know your geography better.

HL: I've come away more convinced than ever that the percentage of people who are intelligent, stupid, beautiful, or whatever is more or less the same all over the world. I don't think any country has a lead on desirable qualities.

WB: I would be happy enough if Americans realized that Trinidad is not a small town in Jamaica. 